УДК 339.923

08.00.00 Экономические науки

СОВРЕМЕННОЕ СОСТОЯНИЕ И ОСОБЕННОСТИ РАЗВИТИЯ ВНЕШНЕЙ И ВЗАИМНОЙ ТОРГОВЛИ СТРАН-УЧАСТНИЦ ЕВРАЗИЙСКОГО ЭКОНОМИЧЕСКОГО СОЮ3А

Фалина Наталья Владимировна

к.э.Н., доцент

РИНЦ SPIN-код $=$ 5366-4838

Сластенко Екатерина Сергеевна магистрант

ФГБОУ ВО «Кубанский государственный аграрный университет имени И.Т. Трубилина», Краснодар, Россия

В данной статье приведен анализ внешней и взаимной торговли стран Евразийского экономического союза как основного показателя развития интеграции. Рассмотрены объемы и структура внешней и взаимной торговли стран-участниц. Выявлены основные тенденции развития торговых отношений и прогноз на их основе. По итогам научного исследования сделан вывод, что Россия является лидером по объему как внешней, так и взаимной торговли среди стран-участниц

ЕврАзЭС, является их ключевым партнером. В этой связи именно Россия во многом определяет интеграционное сотрудничество в рамках союза

Ключевые слова: ЕВРАЗИЙСКИЙ ЭКОНОМИЧЕСКИЙ СОЮЗ; МЕЖДУНАРОДНАЯ ЭКОНОМИЧЕСКАЯ ИНТЕГРАЦИЯ; МЕЖДУНАРОДНАЯ ТОРГОВЛЯ; ИМПОРТ, ЭКСПОРТ; САЛЬДО ВНЕШНЕЙ ТОРГОВЛИ

Doi: 10.21515/1990-4665-130-047
UDC 339.923

Economic sciences

\section{CURRENT STATE AND DEVELOPMENTAL CHARACTERISTICS OF FOREIGN AND MU- TUAL TRADE OF THE EURASIAN ECONOMIC UNION}

Falina Natalya Vladimirovna

Cand.Econ.Sci., Assistant Professor

RSCI SPIN-ID = 5366-4838

\author{
Slastenko Ekaterina Sergeevna \\ Undergraduate \\ Kuban state agrarian University named after I. T. \\ Trubilin, Krasnodar, Russia
}

\begin{abstract}
The article gives a detailed analysis of foreign and mutual trade of the Eurasian economic Union as the main indicator of development integration. It is dealt with the amount and structure of foreign and mutual trade of the participating countries. Attempts are made to formulate and predict the main trends of development trade relations. Conclusions are drawn that Russia prejudges integration cooperation, because it is the leader in most economic indicators within the integration group
\end{abstract}

Keywords: EURASIAN ECONOMIC UNION; ECONOMIC INTEGRATION; INTERNATIONAL TRADE; IMPORT; EXPORT; BALANCE OF TRADE

Евразийский экономический союз - это международная организация региональной экономической интеграции, обладающая международной правосубъектностью и учреждённая Договором о Евразийском экономическом союзе. В ЕврАзЭС обеспечивается свобода движения товаров, а также услуг, капитала и рабочей силы, и проведение скоординированной, согласованной или единой политики в отраслях экономики [1].

Поскольку в мировой экономике все больше возрастает роль интеграционных группировок, важной задачей является анализ интеграционного 
эффекта и те выгоды, которые получают страны от участия в Евразийском экономическом союзе.

Внешняя торговля является одной из важнейших функций любого государства. А качественные и количественные показатели экспорта и импорта, сальдо и общий товарооборот, являются одними из важнейших показателей состояния экономики страны, ее конкурентоспособности. Они позволяют выявить ключевых торговых партнеров каждой из стран ЕврАзЭС на мировом рынке. Поэтому, проследив торговые отношения стран-участниц как внутри Союза, так и с третьими странами, можно сделать вывод о характере и степени интеграции в рамках Евразийского экономического союза. Этим и обусловлена актуальность данного исследования. В этой связи формулируется главная задача - исследование и анализ внутренней и внешней торговли стран-участниц Евразийского экономического союза.

Проблеме интеграции в рамках ЕврАзЭС на сегодняшней день уделяется большое внимание в научных кругах. Так, Е.Ю. Винокуров в своей монографии «Евразийская континентальная интеграция» исследует перспективы и необходимые условия для успешного евразийского интеграционного процесса и предлагает универсальную концепцию евразийской экономической интеграции [6].

В исследовании А.Ю. Кнобеля «Евразийский экономический союз: возможные проблемы и препятствия» рассмотрены вопросы интеграции внутри Союза, а также его взаимодействие с другими странами СНГ и дальнего зарубежья. Показано, что основная проблема интеграции внутри ЕврАзЭС - доминирование перераспределительного мотива над производительным. Оценены масштабы нефтегазового трансферта от России к партнерам по ЕврАзЭС и влияние налогового маневра на его величину [7].

В.В. Барская в своих научных работах исследует историю создания Евразийского экономического союза, ключевые аспекты, на которых бази- 
руется интеграционное сотрудничество, а также основные перспективы дальнейшего развития интеграции в рамках Союза [5].

Для того, чтобы подробней изучить торговые отношения странучастниц ЕврАзЭС был проведен анализ внешней и взаимной торговли стран-участниц ЕврАзЭС в период 2011-2015 гг. По объемам внешней торговли среди стран-участниц Союза Россия является безусловным лидером [4]. Сальдо торгового баланса ЕврАзЭС за весь исследуемый период является положительным. Это свидетельствует о наличии спроса на товары, производимые в ЕврАзЭС (табл. 1).

Таблица 1 - Объемы внешней торговли стран-участниц ЕврАзЭС товарами с третьими странами, 2011-2015 гг., млрд. долл.

\begin{tabular}{|c|c|c|c|c|c|c|}
\hline Страна & 2011 г. & 2012 г. & 2013 г. & 2014 г. & 2015 г. & $\begin{array}{c}2015 \text { г. к } \\
\text { Армения }\end{array}$ \\
- оборот & 4,3 & 4,3 & 4,4 & 4,5 & 3,5 & 77,8 \\
- импорт & 1,1 & 1,1 & 1,1 & 1,2 & 1,3 & 108,3 \\
- экспорт & 3,2 & 3,2 & 3,3 & 3,3 & 2,2 & 66,7 \\
- сальдо & $-2,1$ & $-2,1$ & $-2,2$ & $-2,1$ & $-0,9$ & 142 \\
\hline Беларусь & & & & & & \\
- оборот & 46,1 & 47,5 & 39,4 & 38,1 & 28,8 & 75,6 \\
- экспорт & 26 & 28,8 & 19,4 & 19,9 & 15,7 & 78,9 \\
- импорт & 20,1 & 18,7 & 20,0 & 18,2 & 13,1 & 72,0 \\
- сальдо & 5,9 & 10,1 & $-0,6$ & 1,7 & 2,6 & 152,9 \\
\hline Казахстан & & & & & & \\
- оборот & 97,5 & 107,9 & 107,9 & 98,6 & 60,1 & 61,0 \\
- экспорт & 76,8 & 79,6 & 78,1 & 72,3 & 40,8 & 56,4 \\
- импорт & 20,7 & 28,3 & 29,8 & 26,3 & 19,3 & 73,4 \\
- сальдо & 56,1 & 51,3 & 48,3 & 46,0 & 21,5 & 46, \\
\hline Кыргызстан & & & & & & \\
- оборот & 4 & 4,2 & 4,8 & 4,4 & 3,2 & 72,7 \\
- экспорт & 1,7 & 1,3 & 1,5 & 1,3 & 1,1 & 84,6 \\
- импорт & 2,3 & 2,9 & 3,3 & 3,1 & 2,1 & 67,7 \\
- сальдо & $-0,6$ & $-1,6$ & $-1,8$ & $-1,8$ & -1 & 155,6 \\
\hline Россия & & & & & & \\
- оборот & 760,2 & 774,9 & 781,1 & 727,5 & 483,9 & 66,5 \\
- экспорт & 476 & 481,9 & 486,4 & 460,9 & 315,2 & 68,4 \\
- импорт & 284,2 & 293,0 & 294,7 & 266,6 & 168,7 & 63,3 \\
- сальдо & 191,8 & 188,9 & 191,7 & 194,3 & 146,5 & 75,4 \\
\hline ЕврАзЭС & & & & & & \\
- оборот & 912,1 & 938,8 & 937,6 & 873,1 & 579,5 & 66,4 \\
- экспорт & 581,6 & 592,7 & 586,5 & 555,6 & 374,1 & 67,3 \\
- импорт & 330,5 & 346,1 & 351,1 & 317,5 & 205,4 & 64,7 \\
- сальдо & 251,1 & 246,6 & 235,4 & 238,1 & 168,7 & 70,9 \\
\hline
\end{tabular}


Так суммарный объем внешней торговли товарами государств-членов Евразийского экономического союза с третьими странами за 2015 год составил 579,5 млрд. долл., в том числе экспорт товаров - 374,1 млрд. долл., импорт - 205,4 млрд. долл. По сравнению с 2014 годом объем внешнеторгового оборота в 2015 году сократился на 33,6\%, или на 293,6 млрд. долл., экспорт - на 32,7\% (на 181,5 млрд. долл.), импорт - на 35,3\% (на 112,1 млрд. долл.). Профицит внешней торговли составил 168,7 млрд. долл. против 238,1 млрд. долл. в 2014 году. По сравнению с 2013 годом объем внешнеторгового оборота в 2014 году сократился на 6,9\%, или на 64,5 млрд. долл., экспорт - на 5,3\% (на 31,2 млрд. долл.), импорт - на 9,6\% (на 33,3 млрд. долл.).

Объем внешней торговли стран-участниц ЕврАзЭС оставался почти неизменным за весь исследуемый период. Проанализировав данные таблицы 1 можно сделать вывод о том, что Беларусь, Казахстан и Россия являются импортно-ориентированными странами. Российская Федерация является лидером и по объему экспорта, и по объему импорта. Экспортноориентированными странами являются Армения и Кыргызстан, их сальдо в 2015 году составляет 0,9 и 1 млрд. долл., соответственно.
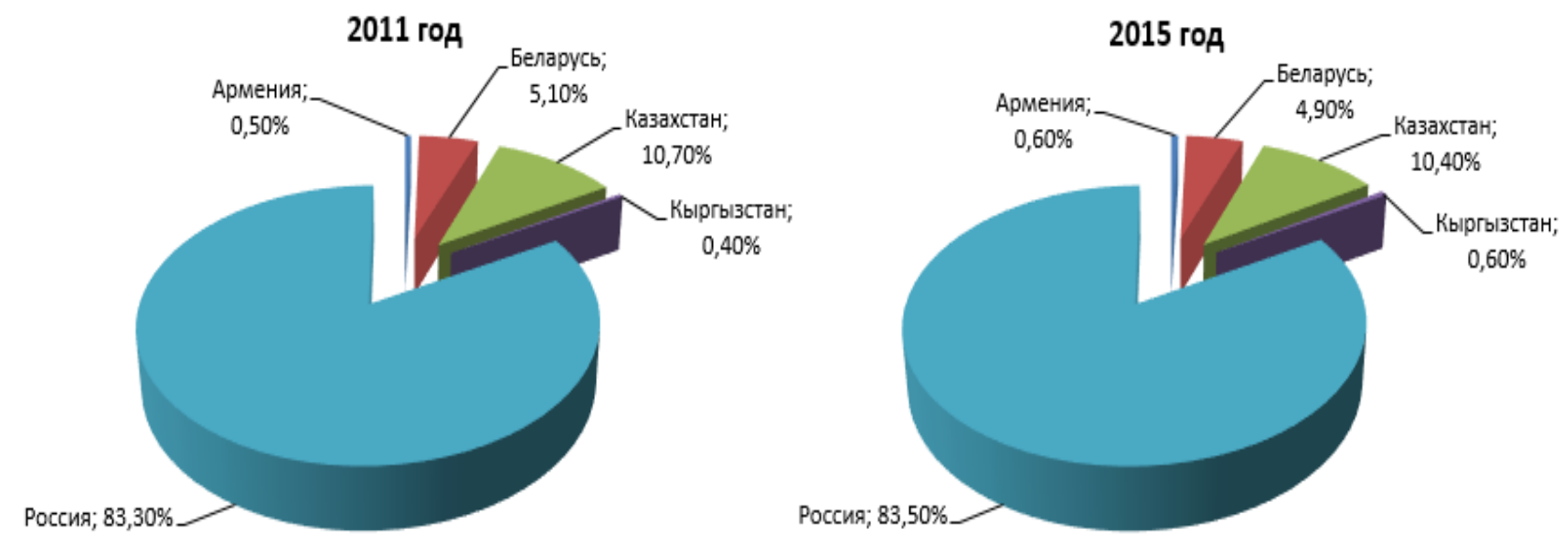

Рисунок 1 - Распределение объемов внешней торговли товарами государств-членов ЕврАзЭС с третьими странами, 2011 и 2015гг., \% 
Российская Федерация имеет наибольший удельный вес в торговле стран-участниц ЕврАзЭС с третьими странами. На ее долю в 2015 году приходится $84,3 \%$ всего экспорта и $82,1 \%$ всего импорта. В суммарном объеме в 2015 и 2011 годах на долю России также приходилось 83\% всего объема внешней торговли с третьими странами. Наименьший удельный вес имеет Армения. Ее доля на 2015 год составляет 0,6\%, на $2011-0,5 \%$ (рис.1).

Для того, чтобы подробнее проанализировать основных торговых партнеров интеграционной группировки, рассмотрим рисунок 2.

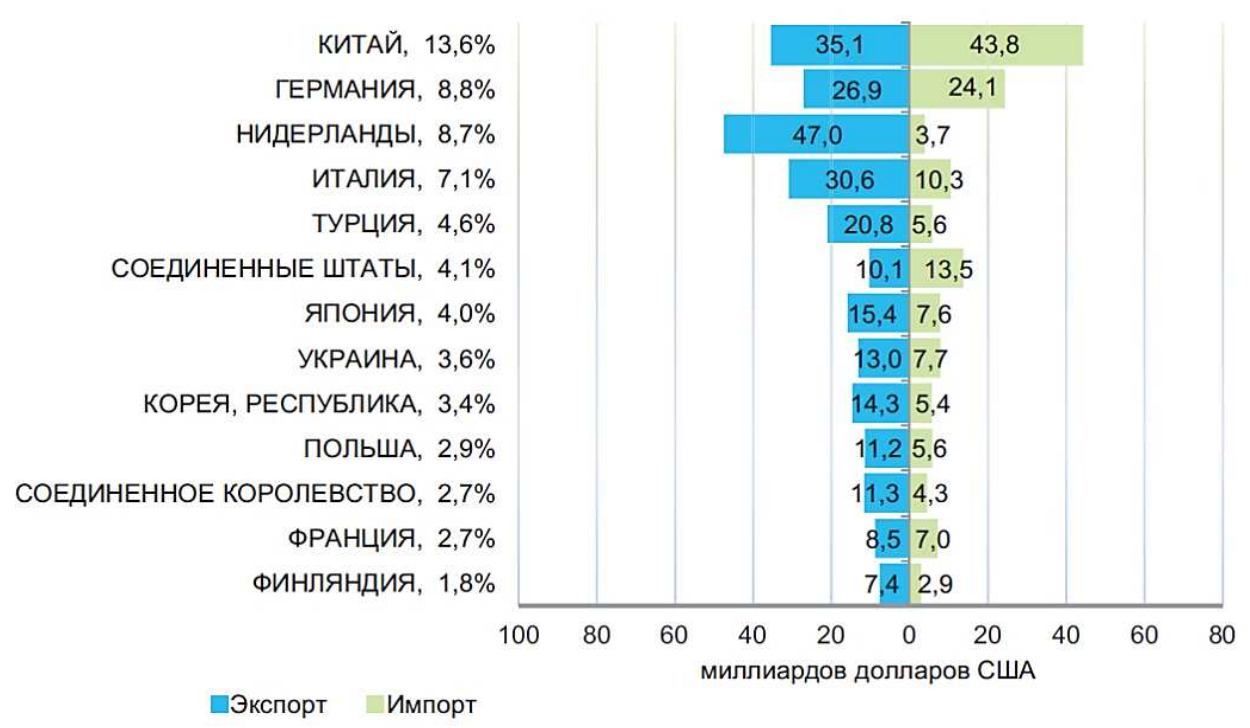

Рисунок 2 - Распределение объемов внешней торговли товарами государств-членов ЕврАзЭС по основным торговым партнерам, 2015г.

Главным торговым партнером стран-участниц ЕврАзЭС является Китай (13,6\% удельного веса в общем объеме торговли). Основным направлением сотрудничества является импорт обрабатывающей промышленности и готовой продукции из Китая.

Нидерланды и Германия занимают по 8,7\% в удельном весе внешней торговли с третьими странами. В 2015 году экспорт в Нидерланды соста- 
вил 47 млрд. долл., а экспорт в Германию - 26,9 млрд. долл. Значительным также является и импорт из Германии - в 2015 году он составил 24,1 млрд. долл.

Наименьшие объемы торговли стран ЕвраАзЭС с третьими странами имеют с Великобританией, Францией и Финляндией. На их долю в 2015 году пришлось $2,7 \%, 2,7 \%$ и $1,8 \%$ объемов торговли, соответственно. Из этих стран преимущественно осуществляется экспорт товаров в страны ЕвраАзЭС.

Однако стоит отметить важную особенность - если рассматривать торговлю со странами Евросоюза в общей совокупности, то именно ЕС является одним из ключевых партнеров Евразийского экономического союза.

Товарная структура экспорта стран-участниц ЕврАзЭС во внешней торговле с третьими странами проиллюстрирована на рисунке 3.
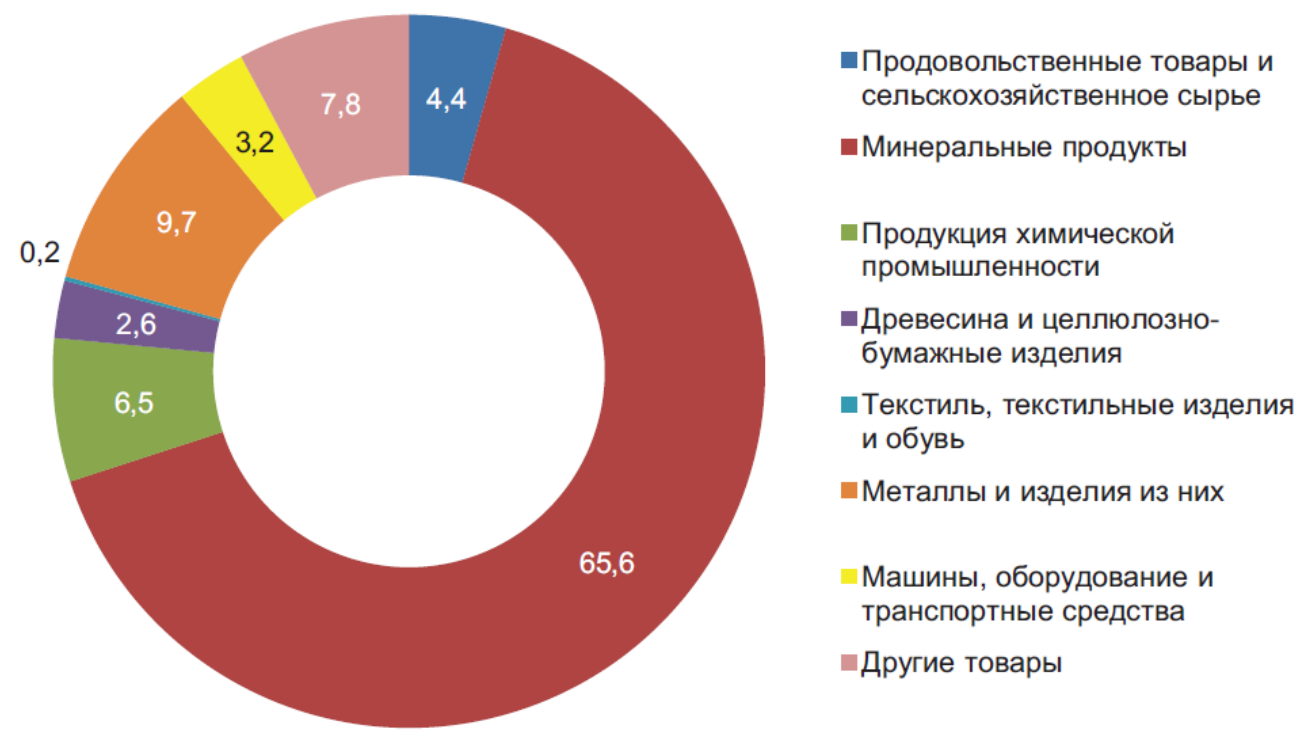

Рисунок 3 - Товарная структура экспорта стран-участниц ЕврАзЭС во внешней торговле с третьими странами, 2015 г.

В товарной структуре экспорта государств-членов ЕврАзЭС в третьи страны в 2015 году преобладают минеральные продукты (65,6\% общего объема экспорта государств-членов ЕврАзЭС в третьи страны), металлы и 
изделия из них (9,7\%), продукция химической промышленности $(6,5 \%)$. Более $80 \%$ этих товаров продает на внешнем рынке Российская Федерация. Наименьшую долю в товарной структуре имеет текстиль, текстильные изделия и обувь $-0,2 \%$.

Структура торговли с Евразийского экономического союза внушает серьёзные опасения: более 2/3 экспорта Союза составляет сырьё, а почти весь импорт - продукция куда более высокого уровня. В долгосрочной перспективе это является негативным фактором, поскольку ставит внешнюю торговлю ЕврАзЭС в зависимость от уровня цен на энергоносители [13].

Товарную структуру импорта во внешней торговле Евразийского экономического союза с третьими странами характеризует рисунок 4.

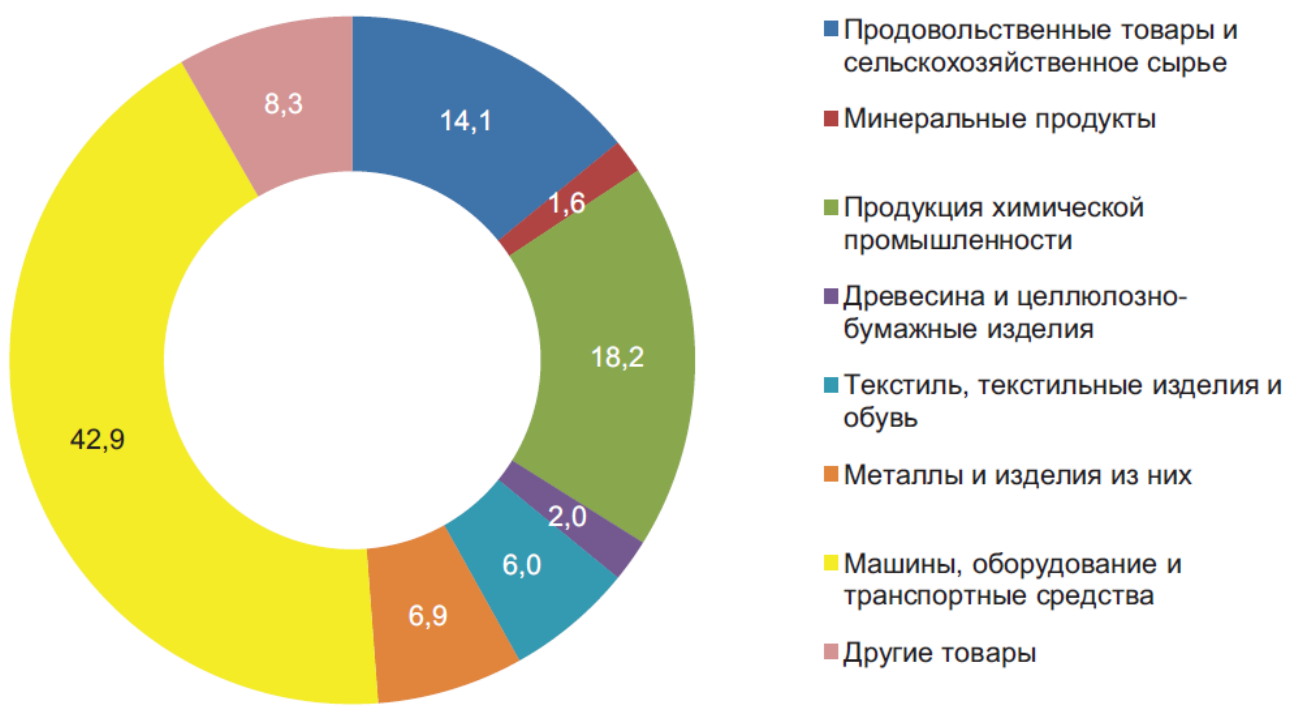

Рисунок 4 - Товарная структура импорта стран-участниц ЕврАзЭС во внешней торговле с третьими странами, 2015 г.

В товарной структуре импорта во внешней торговле с третьими странами за 2015 год преобладает доля машин, оборудования и транспортных средств - 42,9 \%. На долю продукции химической промышленности при- 
ходится 18,2\% внешней торговли стран-участниц Союза. Значительную долю в товарной структуре импорта во внешней торговле занимают также продовольственные товары и сельскохозяйственное сырье - 14,1\%.

Что касается внутренней торговли, то объединение рынков, ресурсов и активов в рамках Евразийского экономического союза имеет два преимущества. Во-первых, более емкий внутренний рынок создает благоприятные условия для достижения экономии масштаба. Во-вторых, тесные связи в рамках технологических цепочек дают необходимую устойчивость и больший объем ресурсов для технологической гонки.

Объем взаимной торговли товарами за 2014 год составил 57,4 млрд. долл., или 89\% к уровню 2013 года. Объем взаимной торговли товарами за 2015 год составил 45,4 млрд. долл., или 74\% к уровню 2014 года. Объемы взаимной торговли по направлениям характеризуют данные, приведенные в таблице 2.

Таблица 2 - Объем взаимной торговли между странами ЕврАзЭС, млн. долл.

\begin{tabular}{|l|c|c|c|c|c|c|}
\hline \multicolumn{1}{|c|}{ Страны } & $2011 г$. & $2012 г$. & $2013 г$. & $2014 г$. & $2015 г$. & $\begin{array}{c}2015 г . \text { к } \\
2014 \text { г., }\end{array}$ \\
\hline Армения - Беларусь & 32,8 & 45,4 & 41 & 38,3 & 33,3 & 86,9 \\
\hline Армения - Казахстан & 6,7 & 4,5 & 8,1 & 7,3 & 5,6 & 76,7 \\
\hline Беларусь - Казахстан & 778,7 & 898,7 & 928,7 & 940,8 & 572,4 & 60,8 \\
\hline Беларусь - Кыргызстан & 225,9 & 153,1 & 110,8 & 95,3 & 69 & 72,4 \\
\hline Казахстан - Кыргызстан & 751,1 & 1035,9 & 1054 & 1206,5 & 863,6 & 71,6 \\
\hline Казахстан - Россия & 22330,6 & 23096,6 & 23847 & 20196,2 & 15187,6 & 75,2 \\
\hline Кыргызстан - Армения & 0,4 & 0,9 & 1,1 & 0,5 & 0,5 & 100 \\
\hline Кыргызстан - Россия & 1443,3 & 1853,2 & 2182,1 & 1856,8 & 1454,4 & 78,3 \\
\hline Россия - Армения & 1007,4 & 1194,5 & 1332,1 & 1397 & 1274,2 & 91,2 \\
\hline Россия - Беларусь & 39991,6 & 43861,1 & 39774,3 & 3774 & 25928,2 & 687,0 \\
\hline ЕврАзЭС & 66568,5 & 72143,9 & 69249,2 & 63112,7 & 45379,8 & 71,9 \\
\hline
\end{tabular}

Наибольший объем взаимной торговли приходится на Россию с другими странами-участниками ЕврАзЭС. Так, в 2011 году взаимная торговля России с Казахстаном составила 22,3 млрд. долл., но сократилась в 2015 году до 15,2 млрд. долл., Наибольший объем взаимной торговли в рамках 
Союза приходится на торговлю между Россией и Беларусью. За исследуемый период данный показатель вырос почти в 7 раз и составил в 2015 году 25928 млрд. долл. Данный факт позволяет сделать вывод, что в рамках интеграционной группировки во внутренней торговле Россия и Беларусь являются ключевыми партнерами друг друга.

Объемы торговли Республики Казахстан в 2015 году произошло сокращение объемов торговли, в особенности с Республикой Беларусь. В 2015 году объем торговли между Россией и Казахстаном сократился на 24,8\% по сравнению с 2014 годом и составил 15,5 млрд. долл.

Республика Армения в 2015 году сократила объем взаимной торговли со всеми странами интеграционной группировки. Ключевым партнером в рамках Союза, как и у всех остальных стран-участниц, является Россия, объем торговли в 2015 году составил 1274 млрд. долл., что составляет 91,2\% от уровня 2014 года.

После вступления в состав ЕврАзЭС Республика Кыргызстан ведет активную торговлю с остальными странами-участницами союза. Но в 2015 году объемы торговли Кыргызстана с другими странами-участницами существенно сократились.

По совокупному объему экспорта в период с 2011 по 2015 годы безусловным лидером является Россия, ее доля за исследуемый период составляет $63,5 \%$. Это значит, что во взаимной торговле стран-участниц ЕврАзЭС преобладает российский экспорт.

В целом по ЕврАзЭС произошло снижение объемов взаимной торговли до 45 млрд. долл., что вызвано по большей части снижением курсов валют по отношению к доллару США.

Структуру взаимной торговли по укрупненным товарным группам за 2015г. года характеризует рисунок 5.

В товарной структуре взаимной торговли государств-членов ЕврАзЭС наибольший удельный вес занимают минеральные продукты (33,4\% объе- 
ма взаимной торговли), из которых 81,7\% на рынок ЕврАзЭС поставляет Российская Федерация.
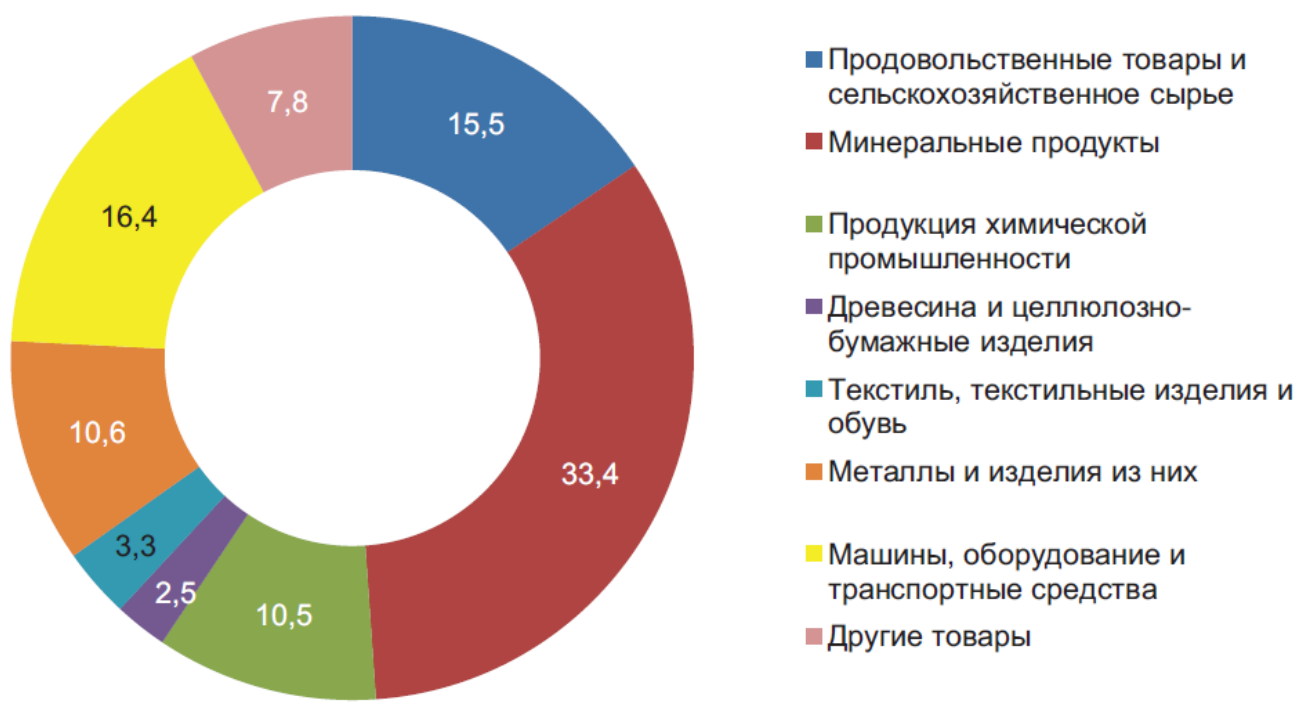

Рисунок 5 - Структура взаимной торговли стран ЕврАзЭС, 2015 г.

Существенны поставки машин, оборудования и транспортных средств (16,4\% объема взаимной торговли), из которых $60 \%$ приходится на Российскую Федерацию и 37,1\% - на Республику Беларусь.

Доля продовольственных товаров и сельскохозяйственного сырья составляет 15,2\% объема взаимной торговли, из которых 56\% приходится на Республику Беларусь и $34,7 \%$ - на Российскую Федерацию. Поставки металлов и изделий из них составляют 10,6\% объема взаимной торговли, из которых 67,2\% приходится на Российскую Федерацию.

За исследуемый период произошло сокращение доли машин и оборудования во взаимной торговле стран-членов ЕврАзЭС. Сначала в 2014 году этот показатель вырос на 2\%, но в 2015 году произошло снижение на 6\% и доля машин и оборудования установилась в размере $16 \%$. Доля остальных групп товаров во взаимной торговле за исследуемый период практически не изменилась. 
Распределение общих объемов внешней торговли товарами по направлениям торговли представлено на рисунке 6.

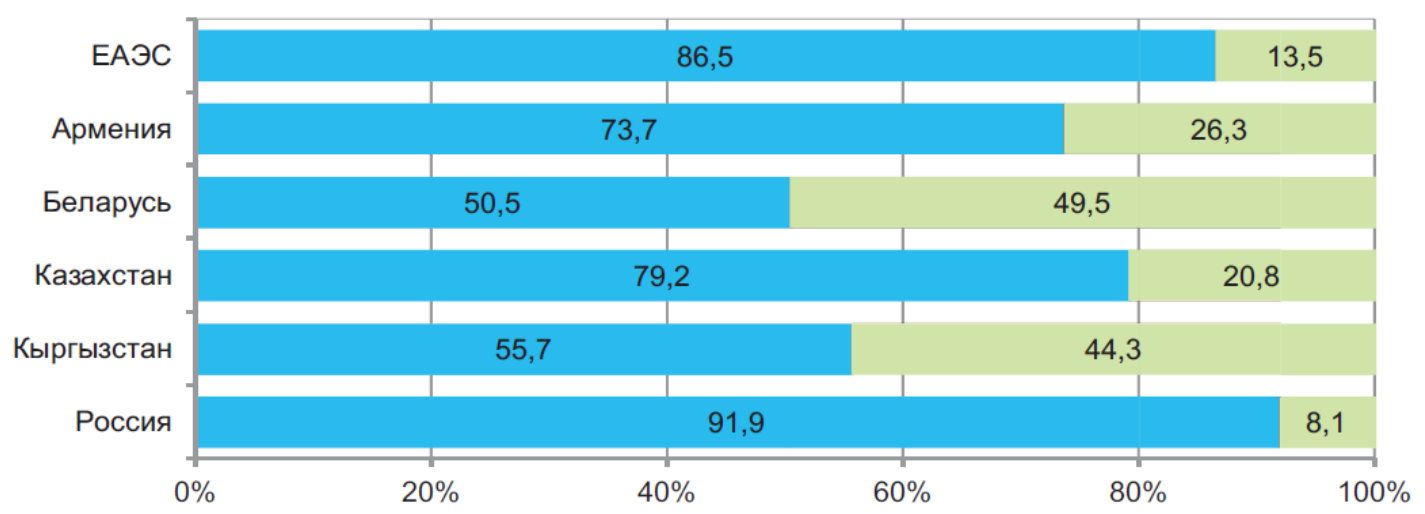

Внешняя торговля товарами с третьим странами Взаимная торговля товарами

Рисунок 6 - Распределение общих объемов внешней торговли товарами по направлениям торговли, 2015 г., \%

Можно сделать вывод, что 86,5\% всей торговли ЕврАзЭС приходится на внешнюю торговлю с третьими странами. В России в 2015 году данный показатель составил почти 92\%. В Казахстане и Армении наибольший удельный вес также приходится на внешнюю торговлю с третьими странами - более $70 \%$.

В Беларуси половина всего объема внешней торговли приходится на внешнюю торговлю, и половина на взаимную. Похожая ситуация наблюдается и в Кыргызстане - 44,3\% всей внешней торговли приходится на торговлю внутри Евразийского экономического союза.

Образование Евразийского экономического союза означает создание общего рынка товаров с классическими эффектами увеличения масштаба и разнообразия, что способствует повышению эффективности и росту экономического потенциала стран-членов. Республика Беларусь, Казахстан, Россия, Армения, Киргизия начали взаимодействовать задолго до того, как соответствующее объединение было учреждено в современном виде. 
По мнению ряда аналитиков, Евразийский экономический союз пример международной организации с поступательным, планомерным развитием интеграционных процессов, что может предопределять значительную устойчивость соответствующей структуры [15].

Прогнозируется, что интеграционный фактор будет способствовать увеличению доли государств-членов в мировой торговле товарами и услугами на 0,2 п.п. к 2030 году, что соответствует описанным выше тенденциям [3]. Не столь существенные значения показателя отражают, в том числе, ориентированность производителей государств-членов на освоение внутреннего рынка Союза (табл. 3).

Таблица 3 - Оценка дополнительных экономических эффектов в результате интеграционного сотрудничества стран-участниц ЕврАзЭС к 2030 году (прогноз)

\begin{tabular}{|c|c|c|c|c|c|}
\hline Наименование показателя & ЕврАзЭС & Армения & Беларусь & Казахстан & Россия \\
\hline $\begin{array}{l}\text { Отношение импорта из треть- } \\
\text { их стран к ВВП, \% }\end{array}$ & -0,2 п.п. & - & - 3,7 п.п. & +5,3 п.п. & -1,0 п.п. \\
\hline $\begin{array}{l}\text { Взаимная торговля товарами } \\
\text { промежуточного потребле- } \\
\text { ния, сырье, материалы, млрд. } \\
\text { долл. }\end{array}$ & $+80,4 \%$ & $+31,3 \%$ & $+65,8 \%$ & $+94,8 \%$ & $+85,0 \%$ \\
\hline $\begin{array}{l}\text { Взаимная открытость торгов- } \\
\text { ли товарами, \% }\end{array}$ & +2,9 п.п. & $\begin{array}{l}+22,0 \\
\text { П.П. }\end{array}$ & $\begin{array}{c}+17,2 \\
\text { П.П. }\end{array}$ & +3,2 п.п. & +1,9 п.п. \\
\hline $\begin{array}{l}\text { Взаимная значимость торгов- } \\
\text { ли товарами, \% }\end{array}$ & +2,8 п.П. & $\begin{array}{c}+11,4 \\
\text { П.П. }\end{array}$ & $\begin{array}{c}+12,8 \\
\text { П.П. }\end{array}$ & +5,3 п.п. & +4,0 п.П. \\
\hline $\begin{array}{l}\text { Взаимная открытость торгов- } \\
\text { ли услугами, \% }\end{array}$ & $\begin{array}{c}+0,03 \\
\text { П.П. }\end{array}$ & - & $\begin{array}{c}+0,15 \\
\text { П.П. }\end{array}$ & -0,05 п.п & $\begin{array}{c}+0,02 \\
\text { П.П. }\end{array}$ \\
\hline $\begin{array}{l}\text { Взаимная значимость торгов- } \\
\text { ли услугами, \% }\end{array}$ & $\begin{array}{c}+0,03 \\
\text { П.П. }\end{array}$ & - & -0,13 п.п. & -0,39 п.п. & $\begin{array}{c}+0,05 \\
\text { П.П. }\end{array}$ \\
\hline $\begin{array}{l}\text { Доля экспорта в мировой тор- } \\
\text { говле, } \%\end{array}$ & $\begin{array}{c}+0,23 \\
\text { П.П. }\end{array}$ & +0,01п.п. & 0,08 п.п. & +0,08 п.п. & $\begin{array}{c}+0,08 \\
\text { П.П. }\end{array}$ \\
\hline
\end{tabular}

В настоящее время наблюдается тенденция к снижению потенциального экономического роста как в развитых странах, так и в странах с формирующимся рынком. В силу вовлеченности государств-членов ЕврАзЭС в глобальные процессы данная тенденция отражается и на их перспективах 
развития. Кроме того, высокая степень геополитической неопределенности и неясные инвестиционные перспективы ускорили тенденцию замедления потенциального выпуска в России, что в результате эффектов от изменения потоков капитала сказывается на партнерах по интеграционному объединению и их торговым отношениям [8].

Важнейшим фактором устойчивости могут стать трансграничные компании и холдинги, имеющие переплетенные активы в ряде стран Евразийского экономического союза. Такие проекты чреваты значительными сложностями, но они формируют скелет долгосрочной экономической интеграции.

Что касается внешней торговли, пока Россия с другими участниками ТС инициировала переговоры о свободной торговле с важными, но заметно менее весомыми по объему экономики отдельными государствами [14, 15], Стоит подчеркнуть, что это имеет большое значение только в том случае, если ориентироваться на повестку модернизационного развития, которая способна серьезно посодействовать тому, чтобы странам ЕврАзЭС вместе и отдельно «не потеряться» в возникающих глобальных и межрегиональных торгово-экономических и инвестиционных конфигурациях [11].

Подводя итоги можно сказать, что Россия остается определяющей силой евразийской экономической интеграции, ее доля в ВВП (88\%) и населении (84\%) интеграционного объединения. В рамках интеграционной группировки Россия является ключевым партнером остальных странучастниц, на ее долю приходится более $80 \%$ всего объема торговли Союза. А это значит, что «здоровье» российской экономики во многом определяет состояние экономик всего ЕврАзЭС.

\section{Литература}

1. Договор о Евразийском экономическом союзе (ЕАЭС) - Высший евразийский экономический совет. - URL: http://www.consultant.ru/

2. Договор о присоединении Армении к ЕАЭС - Высший евразийский экономический совет. - URL: http://www.consultant.ru/ 
3. Долгосрочный прогноз экономического развития Евразийского экономического союза до 2030 года - Режим доступа: http://www.eurasiancommission.org

4. Евразийский экономический союз в цифрах: краткий статистический сборник - Режим доступа: http://www.eurasiancommission.org

5. Барская В.В. ЕврАзЭС и ЕАЭС: история создания и перспективы / В.В. Барская // Экономика и социум. - 2015. - №4(17) - С. 94-103.

6. Винокуров Е.Ю. Евразийская континентальная интеграция / Е.Ю Винокуров, А.М. Либман - Москва, 2012

7. Кнобель А.Ю. Евразийски экономический союз: перспективы развития и возможные препятствия / А.Ю. Кнобель // Вопросы экономики. - 2015. - № 3. - С. 87-108.

8. Мировая экономика: учеб. пособие / И.В. Снимщикова, К.Э. Тюпаков, Н.В. Фалина; под ред. А.Б. Мельников. - Краснодар: КубГАУ, 2009. - 404 с.

9. Мельников А.Б. Внешнеэкономические аспекты обеспечения продовольственной безопасности Российской Федерации / А.Б. Мельников, А.А. Скоморощенко . - Краснодар: КубГАУ, Фонд «Образование. Наука. Инновации». 2016. - 173 с.

10. Мельников А.Б. Сущность и особенности обеспечения внешнеэкономической безопасности РФ в современных условиях / А.Б. Мельников, М.А. Свитенко // Гуманитарные, социально-экономические и общественные науки. - 2015. - № 11-2. - С. 53-57.

11. Российская экономическая модель-6 сценарии будущего: коллективная монография / под общ. ред. А.И. Трубилина, В.И. Гайдука. - Краснодар: ПросвещениеЮг, 2016. - 498 с.

12. Снимщикова И.В. Некоторые теоретические аспекты внешнеэкономической безопасности России / И.В. Снимщикова, Маковка Е.М. // Общество: политика, экономика, право. - 2012. - № 1. - С. 51-54.

13. Самохвалова, Е.К. Экономические последствия вступления России в ВТО / Е.К. Самохвалова, Н.В. Фалина // Экономика и социум. - 2016. - № 1 (20). - С. 839-844. - URL: http://iupr.ru

14. Трубилин, А.И. Внешнеэкономическая деятельность предприятия: учеб. пособие / А.И. Трубилин, А.Б. Мельников, Н.В. Фалина. - Краснодар: КубГАУ, 2011. 219 c.

15. Фалина, Н.В. Анализ структуры и динамики экспорта российской продукции / Н.В. Фалина, Т.С. Чертова // Прорывные экономические реформы в условиях риска и неопределенности: сб. тр. науч.-практич. конф. - Уфа: НИЦ «АЭТЕРНА, 2016. - С. 175182.

16. Фалина, Н.В. Проблемы и перспективы развития Евразийского экономического сообщества / Н.В. Фалина, Е.Г. Чистуха // Экономика и социум. - 2015. - № 12-2. - C. 39-41. - URL: http://iupr.ru

\section{References}

1. Dogovor o Yevraziyskom ekonomicheskom soyuze (YEAES) [Treaty on the Eurasian Economic Union]. Vysshiy yevraziyskiy ekonomicheskiy sovet [the Supreme Eurasian Economic Council]. Available at: http: http://www.consultant.ru/document/cons_doc_LAW_170264/

2. Dogovor o prisoyedinenii Armenii k YEAES [The Treaty on Armenia's accession to the EAEC]. Vysshiy yevraziyskiy ekonomiceskiy sovet [the Supreme Eurasian Economic Council]. Available at: http://www.consultant.ru/document/cons_doc_LAW_169854

3. Dolgosrochnyy prognoz ekonomicheskogo razvitiya Yevraziyskogo ekonomicheskogo soyuza do 2030 goda [Long-term forecast of the economic development of the Eura- 
sian Economic Union until 2030]. Yevraziyskaya ekonomicheskaya komissiya [the Eurasian economic Commission] Available at: http://www.eurasiancommission.org/

4. Yevraziyskiy ekonomicheskiy soyuz $\mathrm{v}$ tsifrakh: kratkiy statisticheskiy sbornik [The Eurasian Economic Union in figures: a brief statistical collection].Yevraziyskaya ekonomicheskaya komissiya [the Eurasian economic Commission] Available at: http://www.eurasiancommission.org/en/act/integr_i_makroec/dep_stat/econstat/Pages/statpub. aspx

5. Barskaya V.V. YevrAzES i YEAES: istoriya sozdaniya i perspektivy [EurAsEC and the EAEC: the history of creation and prospects]. Ekonomika i sotsium [Economics and society]. - 2015. - No. 4 (17) - pp. 94-103. Available at: http://iupr.ru

6. Vinokurov E.U. Yevraziyskaya kontinental'naya integratsiya [Eurasian Continental Integration]. Moscow, 2012

7. Knobel A.U. Yevraziyskiy ekonomicheskiy soyuz: perspektivy razvitiya i vozmozhnyye prepyatstviya [Eurasian Economic Union: development prospects and possible obstacles]. Voprosy ekonomiki [Issues of Economics]. - 2015. - No. 3. - pp. 87-108.

8. Mirovaya ekonomika: ucheb. Posobiye [World Economy: Textbook.]. I.V. Snimshikova, K.E. Tupakov, N.V. Falina; Ed. A.B. Melnikov. Krasnodar: KubSAU, 2009. - 404 p.

9. Melnikov A.B. Formirovaniye kontseptsii prodovolstvennoy bezopasnosti Rossii [Formation of the concept of Russia's food security]. Ekonomika sel'skogo khozyaystva Rossii [Economics of Agriculture of Russia]. - 2016. - No. 12. - pp. 2-7.

10. Melnikov A.B. Sushchnosti osobennosti obespecheniya vneshneekonomicheskoy bezopasnosti RF v sovremennykh usloviyakh [Essence and features of ensuring foreign economic security of the Russian Federation in modern conditions]. Gumanitarnyye, sotsial'noekonomicheskiye i obshchestvennyye nauki [Humanistic, socio-economic and social sciences]. - 2015. - No. 11-2. - pp. 53-57.

11. Rossiyskaya ekonomicheskaya model'-6 stsenarii budushchego [The Russian economic model-6 scenarios of the future]. A.I. Trubilin, V.I. Gaiduk. - Krasnodar: Enlightenment-South, 2016. - 498 p.

12. Snimshchikova I.V. Nekotoryye teoreticheskiye aspekty vneshneekonomicheskoy bezopasnosti Rossii [Some theoretical aspects of Russia's foreign economic security]. Obshchestvo: politika, ekonomika, pravo [Society: politics, economics, law] - 2012. - No. 1. pp. 51-54.

13. Samokhvalova, E.K., Falina N.V. Ekonomicheskiye posledstviya vstupleniya Rossii $\mathrm{v}$ VTO [Economic consequences of Russia's accession to the WTO]. Ekonomika i sotsium [Economics and society]. - 2016. - No. 1 (20). - pp. 839-844. Available at: http://iupr.ru

14 Trubilin, A.I. Melnikov A.B., Falina N.V. Vneshneekonomicheskaya deyatel'nost' predpriyatiya: ucheb. Posobiye [Foreign economic activity of the enterprise: training]. Krasnodar: KubSAU, 2011. - 219 p.

15. Falina, N.V. Analiz struktury i dinamiki eksporta rossiyskoy produktsii [Analysis of the structure and dynamics of exports of Russian products]. Proryvnyye ekonomicheskiye reformy v usloviyakh riska i neopredelennosti: sb. tr. nauch.-praktich. konf. [Breakthrough economic reforms in conditions of risk and uncertainty: coll. Tr. Scientific-practical. Conf.]. Ufa: SIC "AERTERNA", 2016. - pp. 175-182.

16. Falina, N.V. Problemy i perspektivy razvitiya Yevraziyskogo ekonomicheskogo soobshchestva [Problems and prospects of development of the Eurasian economic community]. Ekonomika i sotsium [Economy and society]. - 2015. - No. 12-2. - pp. 39-41. Available at: http://iupr.ru 